Radovan Kovačević

Ekonomski fakultet Univerziteta u Beogradu radovank@ekof.bg.ac.rs

Prevod

obezbedio

autor
FINANSIRANJE DEFICITA TEKUĆEG RAČUNA ZEMALJA JUGOISTOČNE EVROPE

\title{
Rezime
}

Priliv stranog kapitala u zemlje jugoistočne Evrope (JIE) pre izbijanja finansijske krize iz 2008. godine, podržavao je rast domaće tražnje, koja se jednim delom zadovoljavala iz uvoza. To je uslovilo širenje deficita tekućeg računa. Liberalizacija spoljne trgovine je olakšala uvoz i doprinela rastu trgovinskog deficita. Priliv kapitala u ove zemlje pojačan je niskim kamatnim stopama na strana sredstva, kao i povećanim iznosima raspoložive globalne likvidnosti. Snažna domaća tražnja generisala je visoke stope privrednog rasta. Međutim, značajan rast cena i nadnica, pre svega zbog očekivane konvergencije dohotka, oslabio je sektor razmenljivih dobara u ovim zemljama. Rezultat je visok porast strane zaduženosti, bez odgovarajućih kapaciteta za servisiranje dugova, kao i slabljenje konkurentnosti privrede. Olakšavajuća okolnost za ove zemlje je značajan neto priliv stranih direktnih investicija (SDI), kao važan kanal finansiranja deficita tekućeg računa. Kod zemalja ovog regiona je nastupilo prilagođavanje posle izbijanja globalne ekonomske i finansijske krize, uz prateću redukciju deficita tekućeg računa. Međutim, glavni pravac za finansiranje održivog deficita tekućeg računa je povećanje izvozne konkurentnosti i izvoznih prihoda. Na taj način bi se smanjivao trgovinski deficit, a time bi se i deficit tekućeg računa doveo u održive okvire. Neto priliv SDI je alternativni izvor finansiranja deficita koji ublažava teret spoljne zaduženosti. Međutim, i kod ovog vida priliva kapitala mora se imati u vidu mogućnost repatrijacije profita i eventualno povlačenje kapitala, što bi otežalo finansiranje dostignutog deficita tekućeg računa.

Ključne reči: Tekući račun, spoljni dug, jugoistočna Evropa, strane direktne investicije, trgovinska otvorenost, doznake, investicije, izvoz, trgovinski bilans 


\section{FINANCING \\ THE CURRENT \\ ACCOUNT DEFICIT \\ IN SOUTHEASTERN \\ EUROPEAN \\ COUNTRIES}

Radovan Kovačević

Faculty of Economics University of Belgrade radovank@ekof.bg.ac.rs
Translation provided by the author

\section{Summary}

The inflows of foreign capital to the Southeastern Europe (SEE) countries before the outbreak of the global financial crisis in 2008 supported the growth of domestic demand, which was partially satisfied by imports. This conditioned the growth of the current account (CA) deficit. The liberalization of foreign trade has facilitated imports and contributed to the growth of the trade deficit. The capital inflows into these countries have been increased as a result of the low interest rates as well as the increased amounts of available global liquidity. Strong domestic demand has generated high rates of economic growth. However, a significant increase in prices and wages, primarily due to the expected convergence of income, weakened the sector of tradable goods in these countries. The result has been a high increase in external debt, which could adversely affect debt servicing capacities, and weaken the competitiveness of the economy. The mitigating circumstance for these countries is the significant net inflow of foreign direct investment (FDI), as an important channel of financing the CA deficit. The countries of the region have made adjustments after the outbreak of the global economic and financial crisis, with the accompanying reduction in the CA deficit. However, the main direction for financing a sustainable CA deficit is to increase export competitiveness and export revenues. In this way, the trade deficit would be reduced, and the CA deficit may become sustainable. The FDI net inflow is an additional source of financing the deficit, which mitigates the burden of external indebtedness. However, even with this type of capital inflow, one must bear in mind the possibility of repatriation of profit and, eventually, withdrawal of capital, which could make it difficult to finance the CA deficit.

Keywords: current account, external debt, Southeastern Europe, foreign direct investment, trade openness, remittances, investments, exports, trade balance 


\section{Uvod}

Zemlje jugoistočne Evrope su bile suočene sa rastućim deficitom tekućeg računa pre izbijanja globalne finansijske krize 2008. godine. Ovaj deficit je finansiran zaduživanjem $\mathrm{u}$ inostranstvu i prilivom SDI. Kod nekih zemalja deficit tekućeg računa je prešao granicu od 20\% BDP-a. Mada je po razmerana deficit postao neodrživ na srednji rok, glavna teškoća leži u tome što zaduživanjem nisu finansirani proizvodni kapaciteti koji bi mogli proizvoditi za izvoz, već za investicije namenjene proizvodnji za domaće tržište. Preostali deo deficita se odnosio na finansiranje tekuće potrošnje. Spoljna zaduženost većine zemalja JIE približila se pragu od $80 \%$ BDP-a, dakle granici preko koje se prelazi u zonu prezaduženosti, koja donosi otežan pristup međunarodnom tržištu kapitala. Zbog toga su ove zemlje posle izbijanja krize 2008. godine, akcenat sve više stavljale na stimulisanje priliva SDI. Ova sredstva su pogodnija od stranih zajmova jer ne nose teret servisiranja duga, a i rizici njihovog plasmana pripadaju privatnim investitorima.

Povećanje izvozne konkurentnosti a time i izvoza treba da bude glavni kanal za smanjivanje tereta spoljnog duga i finansiranje održivog deficita tekućeg računa. Priliv stranog kapitala u zemlje JIE je uslovljavao apresijaciju realnog deviznog kursa, uz prateće slabljenje izvozne konkurentnosti. U nekim istraživanjima ovim zemljama se sugeriše da ograniče rast nadnica kako bi popravile konkurentnost i deficit tekućeg računa održale pod kontrolom (Gabrisch, 2015). U ovom radu se analiziraju tendencije deficita tekućeg računa zemalja JIE i mehanizmi njegovog finansiranja.

\section{Tendencije deficita tekućeg računa i njegovo finansiranje}

Deficit tekućeg računa zemalja JIE imao je oscilatornu dinamiku u periodu 2000-2015. godine. Posebno ćemo skrenuti pažnju na zemlje zapadnog Balkana koje se nalaze u procesu pristupanja Evropskoj uniji (EU). U grafikonu 1. se daje prosečno stanje salda tekućeg računa zemalja zapadnog Balkana. One su odvojeno prikazane i zbog činjenice da se nalaze u zoni slobodne trgovine. Takođe, zemlje ovog regiona imaju slične karakteristike privredne strukture.
Grafikon 1. Saldo tekućeg računa zemalja zapadnog Balkana (u \% od BDP-a)

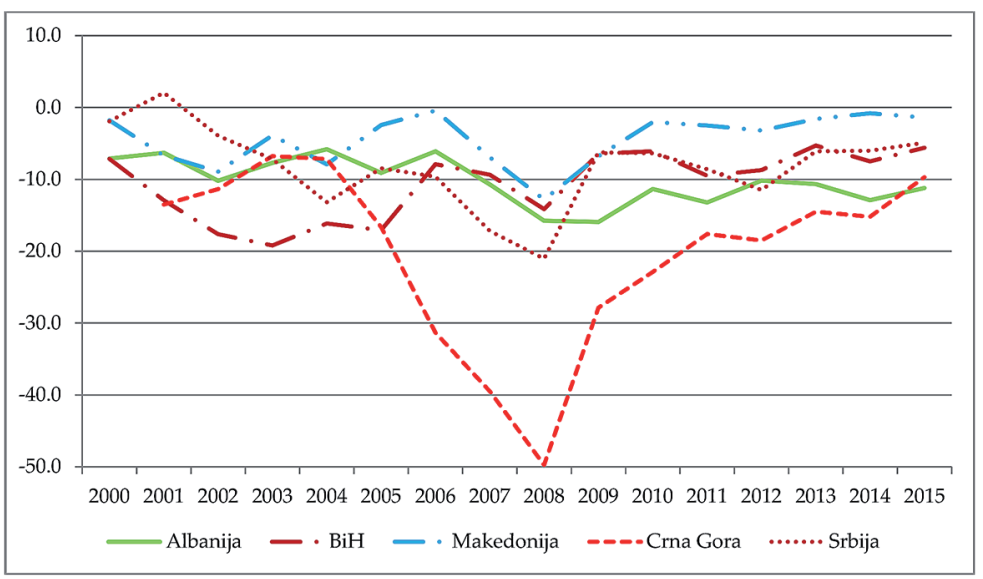

Izvor: IMF, World Economic Outlook Database (October 2016). https://www.imf.org/ external/pubs/ft/weo/2016/02/weodata/weoselgr.aspx Pristupljeno 12.01.2017.
Sve zemlje zapadnog Balkana od 2001. godine formiraju deficit tekućeg računa. Najveća vrednost ovog deficita registruje se u kriznoj 2008. godini. Pri tome je ekstremna vrednost deficita ostvarena u Crnoj Gori. Posle 2008. se registruje usklađeno smanjivanje deficita, i on se kreće u rasponu od 0 do 20\% BDP-a. Sve zemlje zapadnog Balkana deficit tekućeg računa uglavnom finansiraju zaduživanjem $u$ inostranstvu. Na taj način premošćavaju razliku između manje domaće štednje i većih investicija. Ako se strana sredstva ne iskoriste za izgradnju produktivnih kapaciteta, sposobnost zemlje za vraćanje dugova biće umanjena, a vreba je i 


\section{Tendencies of the Current Account Deficit and its Financing}

The SEE countries were faced with a rising CA deficit before the global financial crisis erupted in 2008. This deficit is financed by foreign borrowing and FDI inflows. In some countries, the CA deficit has crossed the limit of $20 \%$ of GDP. Although the deficit has become unsustainable in the medium term, the main difficulty lies in the fact that borrowing is not used to finance the production capacities that could produce for export purposes, but to invest in the production for the domestic market. The rest of the deficit was related to current spending. The external indebtedness of most SEE countries has approached the threshold of $80 \%$ of GDP, that is, the boundary through which it crosses into the indebted area, which makes it difficult to access the international capital market. That is why, after the outbreak of the crisis in 2008, these countries put more and more emphasis on stimulating the FDI inflows. These funds are more favorable than foreign loans because they do not carry the debt servicing burden, and the risks of their placement are carried by private investors.

Figure 1. Current account balance in Western Balkan countries (\% of GDP)

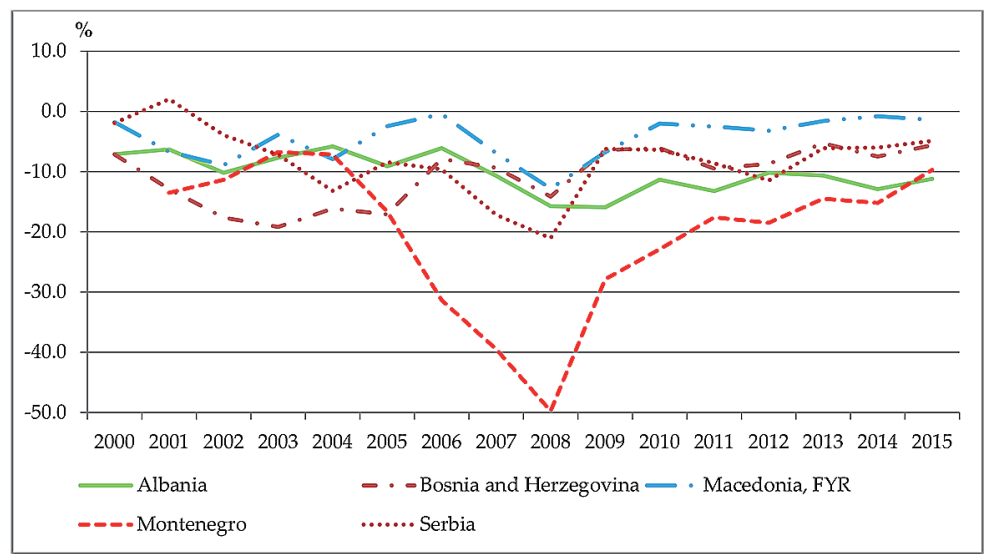

Source: IMF, World Economic Outlook Database (October 2016). https://www.imf.org/ external/pubs/ft/weo/2016/02/weodata/weoselgr.aspx Accessed 12.01.2017
The CA deficit of SEE countries had an oscillatory dynamics in the period from 2000 to 2015. We will pay particular attention to the Western Balkan countries that are in the process of accession to the European Union (EU). Chart 1 shows the average CA balance in the Western Balkan countries. These countries are also shown separately due to the fact that they are in the free trade zone. Also, the countries of this region have similar characteristics in terms of the economic structure.
Increasing export competitiveness and thus exports should be the main channel for reducing the external debt burden and financing a sustainable CA deficit. The inflow of foreign capital into SEE countries conditioned the appreciation of the real exchange rate, with the accompanying weakening of export competitiveness. In some surveys, these countries are suggested to limit wage growth in order to improve competitiveness and CA deficit (Gabrisch, 2015). This paper analyzes the trends in the CA deficit of SEE countries and the mechanisms for its financing. 
nesolventnost. Zbog toga se postavlja pitanje održivosti deficita tekućeg računa. Problemi mogu nastati i zbog iznenadnog povlačenja kapitala, u kom slučaju bi zemlje morale da ostvare suficit tekućeg računa radi urednog vraćanja dugova. Stalan deficit tekućeg računa može povećati ranjivost privrede ovih zemalja. Ovaj se problem može ublažiti stabilnim prilivom dugoročnog kapitala kao što su SDI ${ }^{1}$. Otklanjanjem strukturnih slabosti, može se pojačati ovaj vid priliva kapitala. Radi kompletiranja slike o kretanju salda tekućeg računa ostalih zemalja jugoistočne Evrope, daje se grafikon 2.

Grafikon 2. Saldo tekućeg računa ostalih zemalja jugoistočne Evrope (u \% od BDP-a)

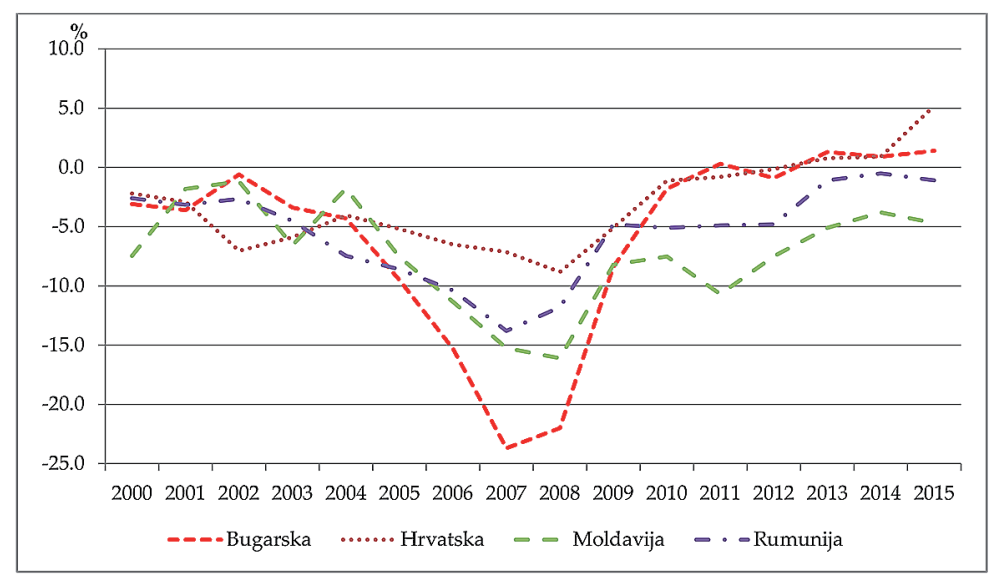

Source: IMF, World Economic Outlook Database (October 2016). https://www.imf.org/ external/pubs/ft/weo/2016/02/weodata/weoselgr.aspx Pristupljeno 12.01.2017.

De Sant, R., 2015, str. 2). U nekim zemljama ovo prilagođavanje je rezultat smanjivanje unutrašnje tražnje i uvoza.

U periodu 2013-2014. godine Hrvatska i Bugarska su ostvarile manji suficit, a druge dve zemlje (Rumunija i Moldavija) su prešle u zonu deficita oko 5\% BDP-a. Rebalansiranje platnog bilansa u članicama evrozone nastalo je zbog većeg pada domaće tražnje nego što je bio pad autputa. Pri tome je pad konjunkture odgovoran za rebalansiranje više nego što je usklađivanje platnog bilansa posledica efekta sustizanja (eng. catching-up effect). Neki autori smatraju da je bum domaće tražnje u periodu pre izbijanja krize iz 2008. godine bio važniji uzrok deficita tekućeg računa u zemljama jugoistočne Evrope nego gubitak cenovne konkurentnosti (Wyplosz, 2013).

Tabela 1. sadrži prosečnu vrednost tekućeg računa kao procenat BDP-a u zemljama jugoistočne Evrope $\mathrm{u}$ periodu 2000-2015. godine. Sve zemlje su u posmatranom periodu imale značajan deficit tekućeg računa (najmanju prosečnu vrednost od 3,1\% imala je Hrvatska), pri čemu je u Bosni i Hercegovini i Crnoj Gori bio veći od $10 \%$. Neponderisana prosečna vrednost deficita je 8,4\% (9,9\%

Posmatrajući dinamiku bilansa tekućeg računa u ostalim zemljama jugoistočne Evrope (grafikon 2) uočava se da su u pretkriznom periodu ove zemlje imale oštar trend pogoršanja bilansa tekućeg računa, posebno u potperiodu 2005-2007. godine. Bugarska i Rumunija su najveći deficit tekućeg računa registrovale 2007. godine, a Hrvatska i Moldavija 2008. godine. Trend smanjivanja deficita tekućeg računa od 2009. godine je očigledan i može se posmatrati kao deo globalnog fenomena strukturnog prilagođavanja platnog bilansa $\mathrm{u}$ evrozoni. Prilagođavanje je bilo posebno naglašeno u perifernim članicama evrozone tokom finansijske krize (Cesaroni, T. and u periodu 2000-2008).

Tabela 1. takođe pokazuje prosečnu vrednost fiskalnog bilansa kao \% BDP-a u posmatranom periodu. $\mathrm{U}$ proseku, posmatrane zemlje su u uzoračkom periodu imale fiskalni deficit od 2,7\%.

Tabela 1. takođe sadrži podatke o prosečnom PPP prilagođenom per capita BDP-u, prosečnoj vrednosti investicione potrošnje i prosečnoj vrednostijavne potrošnje. Prosečna vrednost per capita BDP u celom uzorku tokom posmatranog perioda je 11.459 dolara. Prosečna vrednost koeficijenta investiranja za ceo uzorak je $24,9 \%$, dok je prosečna vrednost javne potrošnje 19,4\%. Većina zemalja jugoistočne Evrope obuhvaćenih ovim uzorkom je imala veći investicioni racio

1 Ovde treba imati u vidu činjenicu da je veliki priliv SDI u zemlje zapadnog Balkana otišao u sektore nerazmenjivih dobara (Kinoshita, 2011). 
sudden withdrawals of capital, in which case the countries would have to make a CA surplus which will be allocated for debt repayment. A steady CA deficit can increase the economic vulnerability of these countries. This problem can be mitigated by a stable inflow of long-term capital such as FDI. ${ }^{1}$ By removing structural weaknesses, this type of capital inflow can be strengthened. For the purpose of completing the picture of the movement of the CA balance in other SEE countries, Figure 2 is given below.

countries (Romania and Moldova) have moved into deficit of around 5\% of GDP. Rebalancing the balance of payments in the euro zone members was due to a decline in domestic demand larger than the decline in output. At the same time, the descending economic activity was responsible for the rebalancing more than the alignment of the balance of payment was the result of the catchingup effect. Some authors believe that the boom in domestic demand in the period before the 2008 was a more important cause of the CA deficit in SEE countries than it was the

Figure 2. CA balance in the other SEE countries (\% of GDP)

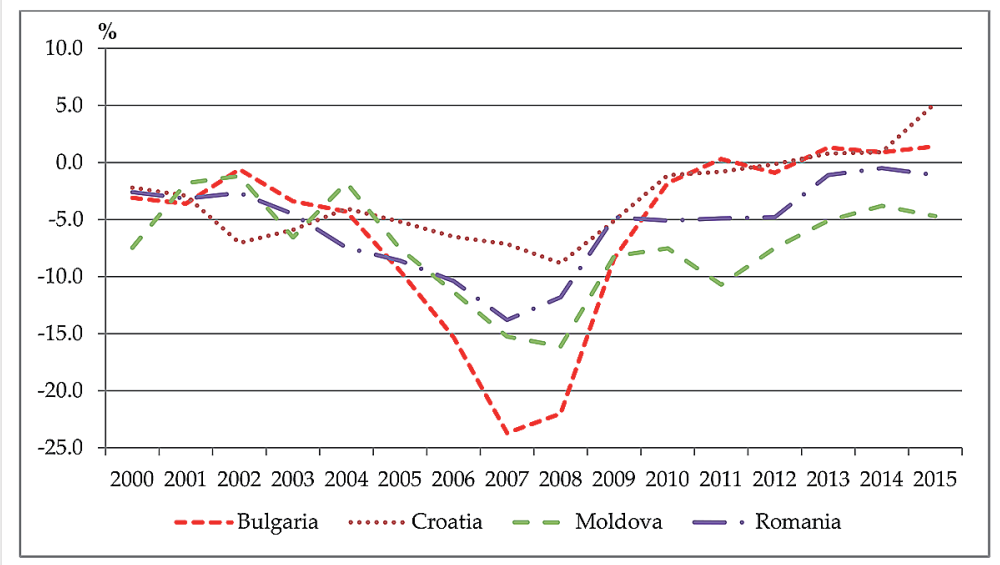

Source: IMF, World Economic Outlook Database (October 2016). https://www.imf.org/ external/pubs/ft/weo/2016/02/weodata/weoselgr.aspx Accessed 12.01.2017 loss of price competitiveness (Wyplosz, 2013).

Table 1 contains the average value of the CA as a percentage of GDP in the SEE countries for the period 2000-2015. All countries had a significant CA deficit in that period (the lowest average value of $3.1 \%$ was in Croatia), but in Bosnia and Herzegovina and Montenegro the CA deficit was higher than $10 \%$. The unweighted average of the CA balance for all SEE countries was $8.4 \%$ (9.9\% for 2000-2008).

The analysis of the dynamics of the CA balance in the other SEE countries (Figure 2) shows that all of them experienced a sharp deterioration of the CA balance in the pre-crisis period, particularly in the sub-period from 2005 to 2007. Bulgaria and Romania registered the largest CA deficit in 2007, and Croatia and Moldova in 2008. A decreasing trend of the CA deficit since 2009 is evident and can be seen as part of the global phenomenon of a structural balance of payments adjustment in the euro area. The adjustment was particularly emphasized in the peripheral Eurozone members during the financial crisis (Cesaroni, T. and De Sant, R., 2015 , p. 2). In some countries this adjustment is the result of a reduction in domestic demand and imports.

Croatia and Bulgaria have made a small surplus in the period 2013-2014, but the other two
Table 1 also shows the average fiscal balance as a percentage of GDP for the sample period. The countries included in the sample period had a fiscal deficit of $2.7 \%$.

Table 1 also shows the average ppp-adjusted GDP per capita, the average value of capital expenditures, and the average values of public consumption. The average value per capita GDP in the observed sample is 11459 USD. The average value of the coefficient of investment for the entire sample was $24.9 \%$, while the average value of public spending is $19.4 \%$. Most SEE countries in this sample had higher investment ratios than the average for the OECD countries $(21.7 \%)$ and the EU (21.2\%). At the same time, the average value of public spending (public spending ratio) in the SEE countries was lower than in the OECD countries (20.4\%), but higher than in the EU (17.9\%). 
nego što je prosek za zemlje OECD $(21,7 \%)$ i EU $(21,2 \%)$. Istovremeno je prosečna vrednost javne potrošnje kod zemalja jugoistočne Evrope bila manja nego u zemljama OECD $(20,4 \%)$, ali veća nego u EU (17,9\%).
Koeficijenti determinacije u grafikonu 3. imaju male vrednosti jer su izračunati iz odnosa informacija a ne na uzročno-posledičnim vezama posmatranih makroekonomskih veličina.
Tabela 1. Izabrani pokazatelji zemalja jugoistočne Evrope u periodu 2000-2015. godine*

\begin{tabular}{|c|c|c|c|c|c|c|c|}
\hline & \multicolumn{3}{|c|}{ Tekući račun } & \multirow{2}{*}{\begin{tabular}{|c}
$\begin{array}{c}\text { Fiskalni } \\
\text { bilans }\end{array}$ \\
Prosek
\end{tabular}} & \multirow{2}{*}{\begin{tabular}{|c|} 
P/c BDP \\
Prosek
\end{tabular}} & \multirow{2}{*}{\begin{tabular}{|c|} 
Investicije \\
Prosek
\end{tabular}} & \multirow{2}{*}{$\begin{array}{c}\begin{array}{c}\text { Javna } \\
\text { potrošnja }\end{array} \\
\text { Prosek }\end{array}$} \\
\hline & Prosek & Minimalno & Maksimalno & & & & \\
\hline Albanija & $-10,3$ & $-15,9$ & $-5,8$ & $-4,9$ & 8057 & 33,8 & 10,7 \\
\hline \begin{tabular}{|l|} 
Bosna i \\
Hercegovina
\end{tabular} & $-10,7$ & $-19,2$ & $-5,3$ & $-2,0$ & 8493 & 20,4 & 18,0 \\
\hline Bugarska & $-5,8$ & $-23,7$ & 1,4 & $-0,3$ & 13737 & 24,7 & 22,4 \\
\hline Hrvatska & $-3,1$ & $-8,8$ & 5,2 & $-4,8$ & 19370 & 24,0 & 19,4 \\
\hline Makedonija & $-4,4$ & $-12,8$ & $-0,4$ & $-2,0$ & 10433 & 24,3 & 19,5 \\
\hline Moldavija & $-7,3$ & $-16,1$ & $-1,2$ & $-1,5$ & 3597 & 26,5 & 18,1 \\
\hline Crna Gora & $-20,2$ & $-49,8$ & $-6,8$ & $-2,8$ & 12577 & 22,7 & 23,1 \\
\hline Rumunija & $-5,5$ & $-13,8$ & $-0,5$ & $-3,2$ & 15754 & 25,8 & 15,9 \\
\hline Srbija & $-8,1$ & $-21,1$ & 2,1 & $-2,6$ & 11113 & 21,6 & 19,4 \\
\hline
\end{tabular}

Napomena * Svi pokazatelji su iskazani u procentima od GDP-a, izuzev dohotka koji predstavlja per capita BDP (konstantni dolari iz 2011).

Izvor: World Bank, World Development Indicators (WDI) (za BDP, per/capita BDP, investicije); IMF, World

Economic Outlook (WEO) Data Base (October 2016) (za tekući račun i fiskalni bilans).

Zn a čajan deo SDI $u$ zemljama JIE u procesu tranzicije i privatizacije je plasiran u sektor nerazmenljivih dobara, što je umanjilo njihov uticaj na izvoz. Deficit tekućeg računa pre izbijanja krize iz 2008. značajno je pokrivan p r i 1 i v o m

Da bi ukazali na neke važnije međusobne odnose makroekonomskih varijabli, u grafikonu 3. se daje prikaz odnosa prosečne vrednosti tekućeg računa naspram fiskalnog bilansa, per capita BDP, investicionog količnika i količnika javne potrošnje, između zemalja.

Grafikon 3. Međuodnosi zemalja - prosečne vrednosti u periodu 2000-2015. godine
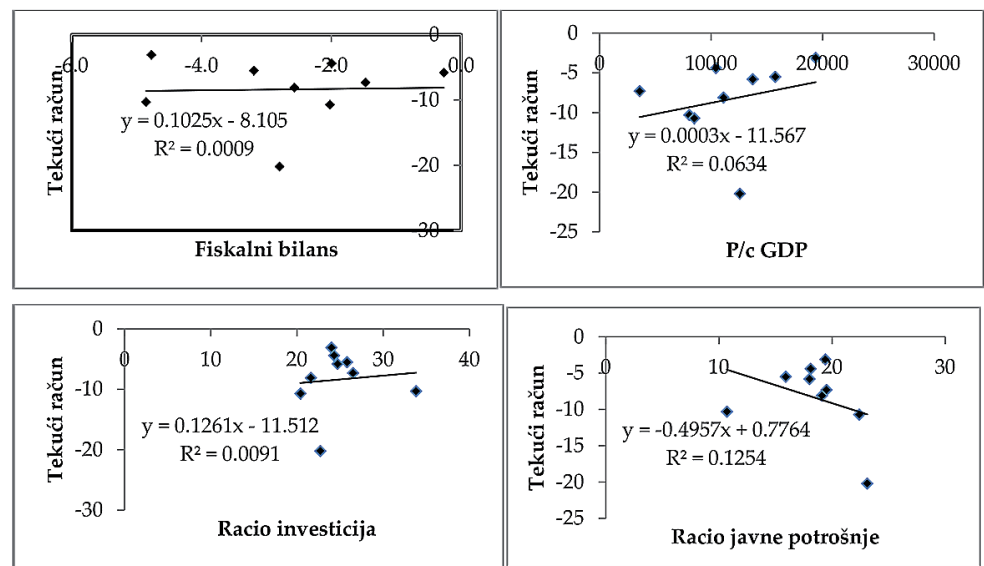

Izvor: Tabela 1.

Dijagram racija investicija u grafikonu 3. odstupa od pretpostavljene međuzavisnosti $\mathrm{u}$ intertemporalnom modelu, dok su ostali dijagrami u skladu sa pretpostavkama modela. stranog kapitala. Pad kamatnih stopa na međunarodnom tržištu kapitala omogućio je zaduživanje pod povoljnim uslovima, što je ubrzalo kumuliranje spoljnog duga i porast deficita tekućeg računa. Porast duga nije bio praćen porastom kapaciteta za servisiranje ovog duga. Apresijacija nacionalnih valuta, podstaknuta velikim prilivom stranog kapitala, dovela je do pogoršanja izvozne konkurentnosti. Posle izbijanja krize, kod svih zemalja je došlo do redukcije deficita tekućeg računa, pre svega zbog slabljenja privredne aktivnosti i smanjivanja uvoza. Liberalizacija spoljne trgovine je sem pozitivnog uticaja na konkurentnost privrede i jačanje konkurencije na domaćem tržištu, otvorila kanal za širenje deficita tekućeg računa. $\mathrm{Na}$ taj način je rast otvorenosti privrede nametnuo pitanje održivosti rastućeg deficita tekućeg računa. U grafikonu 4. su prikazane tendencije kretanja otvorenosti privrede zemalja zapadnog Balkana. 
Table 1: Selected indicators of the SEE countries in the period 2000-2015*

\begin{tabular}{|c|c|c|c|c|c|c|c|}
\hline & \multicolumn{3}{|c|}{ Current account } & \multirow{2}{*}{\begin{tabular}{|c|}
$\begin{array}{c}\text { Fiskal } \\
\text { bal. }\end{array}$ \\
Average \\
\end{tabular}} & \multirow{2}{*}{$\begin{array}{l}\mathrm{P} / \mathrm{c} \text { GDP } \\
\text { Average }\end{array}$} & \multirow{2}{*}{$\begin{array}{c}\text { Invest. } \\
\text { Average }\end{array}$} & \multirow{2}{*}{$\begin{array}{c}\text { Pub. } \\
\text { spend } \\
\text { Average }\end{array}$} \\
\hline & Average & Min & Max & & & & \\
\hline Albania & -10.3 & -15.9 & -5.8 & -4.9 & 8057 & 33.8 & 10.7 \\
\hline $\begin{array}{l}\text { Bosnia and } \\
\text { Herzegovina }\end{array}$ & -10.7 & -19.2 & -5.3 & -2.0 & 8493 & 20.4 & 18.0 \\
\hline Bulgaria & -5.8 & -23.7 & 1.4 & -0.3 & 13737 & 24.7 & 22.4 \\
\hline Croatia & -3.1 & -8.8 & 5.2 & -4.8 & 19370 & 24.0 & 19.4 \\
\hline Macedonia & -4.4 & -12.8 & -0.4 & -2.0 & 10433 & 24.3 & 19.5 \\
\hline Moldova & -7.3 & -16.1 & -1.2 & -1.5 & 3597 & 26.5 & 18.1 \\
\hline Montenegro & -20.2 & -49.8 & -6.8 & -2.8 & 12577 & 22.7 & 23.1 \\
\hline Romania & -5.5 & -13.8 & -0.5 & -3.2 & 15754 & 25.8 & 15.9 \\
\hline Serbia & -8.1 & -21.1 & 2.1 & -2.6 & 11113 & 21.6 & 19.4 \\
\hline
\end{tabular}

Note * All figures are expressed as a percentage of GDP, with the exception of income which represents the per capita GDP (USD, constant 2011 international \$).

Source: World Bank, World Development Indicators (WDI) (for GDP, Per/capita GDP, Investment); IMF World Economic Outlook (WEO) Data Base (October 2016) (for Current Account and Fiscal Balance).

A significant part of FDI in the SEE countries, which are in the process of transition and privatization, has gone into production non-tradable goods, which reduced their impact on exports. Before the onset of the 2008 crisis

To indicate some important mutual relations, Figure 3 gives the overview relations between the average value of the CA and fiscal balance, per capita GDP, investment ratio and ratio of public spending among the countries.

Figure 3. Cross country relationships - average value 1990-2015
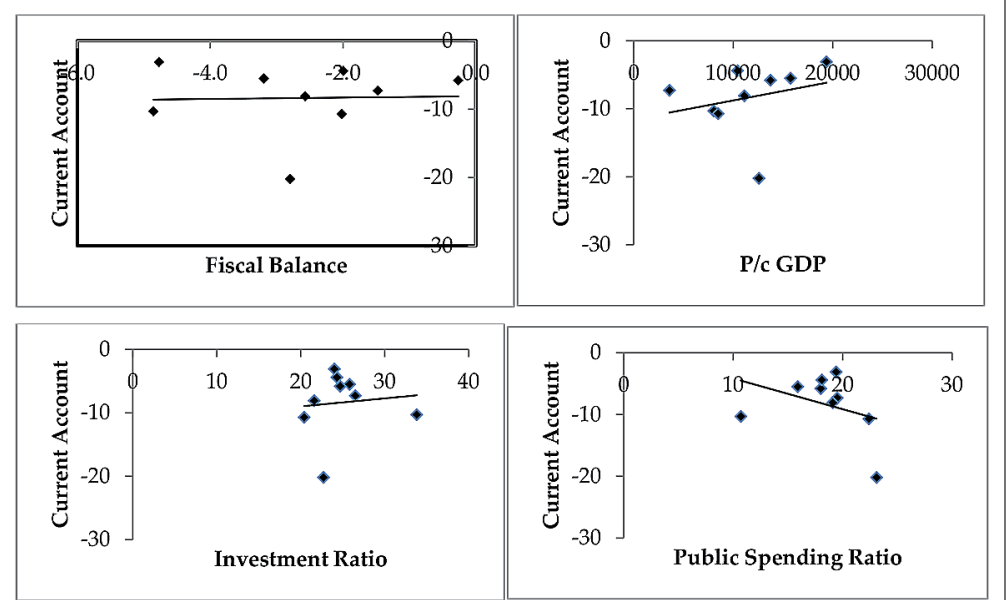

Source: Table 1.

The diagram of investments ratio deviates from the hypothesized relationships of the intertemporal model, while the other diagrams are in accordance with the assumptions of the model. The coefficients of determination in Figure 3 have little value because they are calculated based on the relations between information rather than the cause-and-effect relationships of the observed macroeconomic variables. the CA deficit was significantly supported by inflows of foreign capital. The decline of the interest rates on international capital markets facilitated borrowing under favorable terms, which accelerated the accumulation of foreign debt and the CA deficit increase. The increase in debt has not been accompanied by the increase in capacity to service this debt. The appreciation of the national currency, spurred by the large inflows of foreign capital, has led to the deteriorated export competitiveness. After the outbreak of the crisis, all countries recorded a reduction in their CA deficits, primarily due to the weakening of economic activity and the reduction of imports. The liberalization of foreign trade has had not only a positive impact on the competitiveness of the economy and the strengthening of competition on the domestic market, but has also opened up the channel for increasing the CA deficit. In this way, the increasing openness of the economy imposed the issue of sustainability of the growing CA deficit. Chart 4 shows the tendencies of the openness of the economy of the Western Balkan countries. 
Grafikon 4. Trgovinska otvorenost zemalja zapadnog Balkana

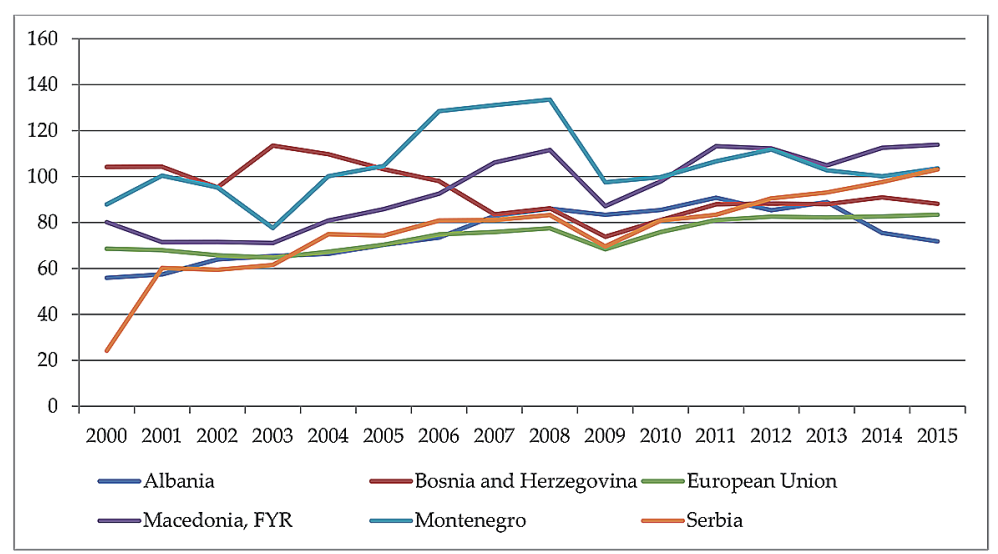

Izvor: The World Bank, http://data.worldbank.org/indicator/NE.EXP.GNFS. ZS?view=chart Pristup 20.08.2017.

i njegov privredni razvoj. Dugo zanemarivana, ova infrastruktura je u brojnim slučajevima ograničavajući činilac povećanja izvoza (Sanfey et al., 2016, str. 27). Snažnije međusobno povezivanje zemalja zapadnog Balkana u sklopu CEFTA sporazuma, kao i potpisani sporazumi o stabilizaciji i pridruživanju EU otvaraju prostor za porast udela njihovog izvoza robe i usluga $u$ BDP-u.

Zaduživanje $\mathrm{u}$ inostranstvu je tradicionalni vid finansiranja

Trgovinska otvorenost u grafikonu 4 . prikazana je kao količnik zbira uvoza i izvoza robe i usluga u odnosu na BDP, za svaku zemlju pojedinačno, i za EU. Globalno posmatrano, zapaža se da je stepen otvorenosti kod zemalja zapadnog Balkana opao u 2009. godini, kad je globalna finansijska kriza svom žestinom pogodila ovaj region. Zatim je usledio trend oporavka ovog pokazatelja. Region ne zaostaje, prema ovom pokazatelju, za zemljama EU. Zapravo, trgovinska otvorenost većine zemalja zapadnog Balkana veća je nego u EU. Ovaj rezultat je posledica većeg udela uvoza robe i usluga u BDP-u zemalja zapadnog Balkana nego kod EU. Perzistentan trgovinski deficit zemalja ovog regiona, i visoka spoljna zaduženost umanjuju doprinos neto trgovine privrednom rastu. Manji udeo izvoza zemalja zapadnog Balkana u njihovom BDP-u u poređenju sa EU nastaje zbog njihove manje integrisanosti u evropske lance isporuke, kao što to potvrđuje novija studija OECD (2013). Takođe, manja je sofisticiranost industrijskih proizvoda koji se izvoze nego što je to slučaj u EU. Kod većine zemalja zapadnog Balkana u izvozu dominiraju radno i resursno intenzivni proizvodi, ili proizvodi niže tehnološke intenzivnosti. Za razliku od zemalja zapadnog Balkana, zemlje EU imaju visok udeo tehnološki intenzivnog izvoza, i njihova specijalizacija ide $\mathrm{u}$ tom pravcu. Sa ovakvom slikom suočice se zemlje zapadnog Balkana u momentu stupanja u članstvo EU. Dinamičnoinvestiranjeu infrastrukturu u regionu, sa istaknutom ulogom kineskih investicija, postaje važan činilac u podizanju izvoza na viši nivo. Dobro razvijena saobraćajna infrastruktura važna je pretpostavka za konkurentnost regiona deficita tekućeg računa zemalja JIE. Da bismo ocenili stepen spoljne zaduženosti ovih zemalja koristićemo grafikon 5 .

Većina zemalja JIE je imala tendenciju rasta koeficijenta spoljnog duga (količnik između stanja spoljnog duga i izvoza robe, usluga i primarnog dohotka) u periodu od 2000. do 2009. godine. Dinamičan skok ovog koeficijenta je ostvaren u periodu 2006-2009. godine, da bi, zatim, usled svetske finansijske krize, usledio njegov pad. Očigledno je da su sve zemlje JIE imale značajan oslonac na zaduživanje $u$ inostranstvu kao izvor finansiranja deficita tekućeg računa. Pad svetske uvozne tražnje usled izbijanja globalne ekonomske krize $\mathrm{u}$ svetu 2008. godine je uslovio smanjivanje rasta izvoza, tako da je oslabio i ritam zaduživanja zemalja JIE u inostranstvu. Ciklični faktori, kao što je slaba uvozna tražnja, niske cene sirovina i malaksavanje privrednog rasta u Kini, zajedno su doprineli padu svetske trgovine (World Bank Group, 2017, str. 61; Constantinescu et al., 2015).

Korporativni sektor u zemljama sa tržištem u nastajanju i zemljama u razvoju (ZUR) pokazuje izuzetnu finansijsku osetljivost $\mathrm{u}$ periodu posle izbijanja globalne finansijske krize, jer mu je oslabila solventnost (Alfaro et al., 2017). U vreme oštrih finansijskih stresova, privatni sektor može biti izvor destabilizacije javnog sektora. To se vidi na primeru nekih zemalja sa tržištem u nastajanju koje su pre izbijanja finansijske krize 2008. godine bile izložene sistemskoj bankarskoj krizi, koja je zahtevala značajnu državni finansijsku pomoć. Ovi izdaci značajno su uvećali javni dug koji je već bio visok zbog fiskalne neravnoteže (Laeven and 
Chart 4: Trade openness of Western Balkan countries

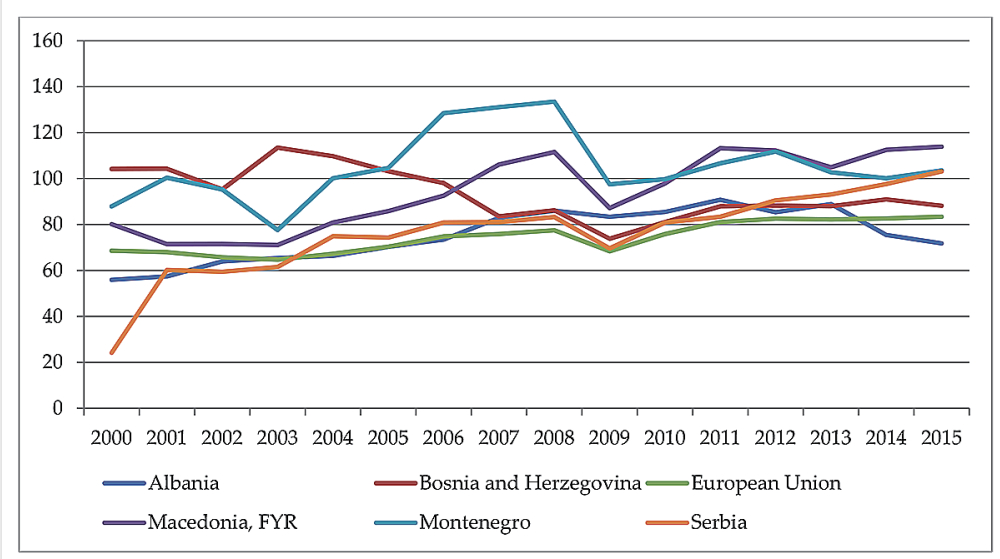

Source: The World Bank, http://data.worldbank.org/indicator/NE.EXP.GNFS. ZS? view=chart Accessed 20.08.2017

Trade openness in Chart 4 is shown as the ratio of imports and exports of goods and services in relation to GDP, for each country individually, and for the EU. Globally, it can be noticed that the degree of openness in the Western Balkan countries declined in 2009, when the global financial crisis strongly affected this region. This was followed by the trend of recovery of this indicator. According to this indicator, the region does not lag behind the EU countries. In fact, the trade openness of most Western Balkan countries is higher than in the EU. This is a result of the higher share of imports of goods and services in the GDP of the Western Balkan countries than in the EU. The persistent trade deficit of the countries in this region, and high external indebtedness, reduce the contribution of net trade to economic growth. The smaller share of Western Balkan countries' exports in their GDP compared to the EU is due to their lower integration into the European supply chains, as confirmed by a recent OECD study (2013). Also, the exported goods are less sophisticated compared to the EU. In most of the Western Balkan countries, the exports are dominated by labor and resource intensive products, or products of lower technological intensity. Unlike the Western Balkan countries, the EU countries have a high share of technologically intensive exports, and their specialization goes in that direction. With this picture, the Western Balkan countries will face the moment of joining the EU. The dynamic investment in infrastructure in the region, with a prominent role of the Chinese investments, is becoming an important factor in raising exports to a higher level. The well-developed transport infrastructure is an important prerequisite for the competitiveness of the region and its economic development. Long neglected, this infrastructure in many cases is a limiting factor in the increasing of exports (Sanfey et al., 2016, p. 27). A stronger interconnection among the Western Balkan countries within the CEFTA agreement, as well as the signed EU Stabilization and Association Agreements, open the space for increasing the share of their export of goods and services in GDP.

The traditional form of financing the CA deficit of SEE countries is borrowing from abroad. In order to assess the degree of external indebtedness of these countries, we will use Chart 5.

Many SEE countries had a tendency to increase the external debt ratio (the ratio between external debt and exports of goods, services and primary income) in the period from 2000 to 2009. A dynamic jump in this coefficient was achieved in the period 2006-2009, and then, as a result of the global financial crisis, there was a decline. It is obvious that all SEE countries had a significant basis for borrowing from abroad as a source of financing the CA deficit. The fall in the world import demand, due to the outbreak of the global economic crisis in 2008, led to a slowdown in export growth, which also weakened the pace of external borrowing of the SEE countries. Cyclical factors, such as the weak import demand, low raw material prices and slowing economic growth in China, have contributed to the decline in world trade (World Bank Group, 2017, p. 61; Constantinescu et al., 2015).

The corporate sector in the emerging markets and developing countries shows remarkable financialsensitivity in the period aftertheoutbreak of the global financial crisis, as it weakened its solvency (Alfaro et al., 2017). In the periods of severe financial stress, the private sector can be a source of the public sector's destabilization. It can be the case of some emerging markets that were exposed to a systemic banking crisis before 
Valencia, 2013). Visoka zaduženost privatnog sektora u zemljama jugoistočne Evrope takođe može biti faktor destabilizacije javnog sektora u tim zemljama. To dolazi do izražaja u onim zemljama koje imaju visok i rastući koeficijent loših bankarskih plasmana.

$\mathrm{Na}$ drugoj strani, oživljavanje izvoza poslednjih godina je doprinelo povećanju izvoznih prihoda, što je uticalo na smanjivanje gore definisanog koeficijenta spoljnog duga. Ipak, kod nekoliko zemalja JIE vrednost ovog koeficijenta prelazi $200 \%$. To zapravo ukazuje da je nivo spoljne zaduženosti zemalja ovog regiona visok, i da se u narednim godinama oslonac mora tražiti u povećanom prilivu SDI. $\mathrm{Na}$ taj način se relaksira servisiranje inače visokog fonda spoljnog duga i stvara mogućnost za održavanje manjeg deficita tekućeg računa bez dodatnog zaduživanja $u$ inostranstvu. Međutim, ne sme se izgubiti iz vida da veliki priliv SDI znači da se $u$ budućnosti može očekivati repatrijacija ostvarenog profita a ne njegovo beskonačno reinvestiranje. To će značiti povećan odliv kapitala, uz smanjivanje neto priliva SDI kao važnog izvora za finansiranje deficita tekućeg računa. U tom momentu zemlje će morati da pristupe reduciranju deficita tekućeg računa i njegovom svođenju u održive okvire primerene raspoloživim izvorima za njegovo finansiranje.

Grafikon 5. Stanje spoljnog duga zemalja JIE kao procenat od izvoza robe, usluga i primarnog dohotka

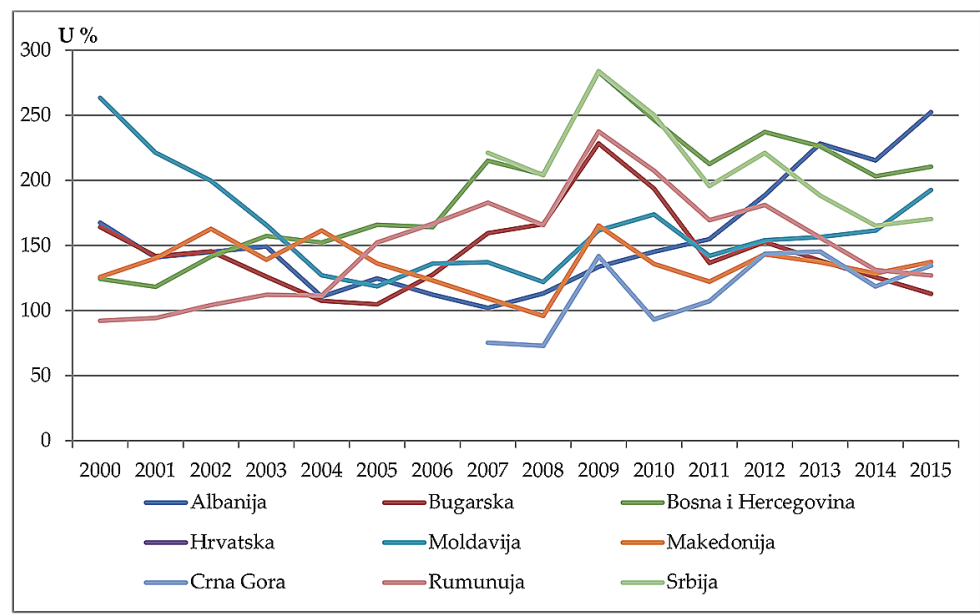

Izvor: The World Bank, http://data.worldbank.org/indicator/NE.EXP.GNFS. ZS?view=chart Pristup 20.08.2017.
Značajan izvor za finansiranje deficita tekućeg računa zemalja jugoistočne Evrope je neto priliv SDI. Tendencije priliva ovih sredstava daju se u grafikonu 6 .

Štednja u zemljama zapadnog Balkana je još uvek manja od investicionih zahteva, tako da se nesklad popunjava stranim sredstvima. Širenje deficita tekućeg računa, podstaknuto ubrzanjem privredne aktivnosti $u$ periodu pre izbijanja globalne ekonomske krize 2008. godine, $\mathrm{u}$ velikoj meri je finansirano prilivom SDI, kao i stranim zajmovima. Međutim, značajan deo ovog priliva bio je usmeren $u$ sektore koji proizvode za domaće tržište. Zbog toga ova sredstva nisu značajnije uticala na rast produktivnosti niti na proširenje proizvodnje namenjene izvozu. Paralelno sa porastom deficita tekućeg računa, rastao je suficit finansijskog računa zemalja zapadnog Balkana. Usled toga je otvorena tendencija rasta deviznih rezervi, koje su dostigle i dvostruko veće iznose od uobičajenih. Za većinu zemalja zapadnog Balkana SDI predstavljaju glavni izvor spoljnog finansiranja (The World Bank, 2016 str. 9).

$\mathrm{Na}$ osnovu tekućih tendencija na međunarodnom tržištu kapitala, stiče se utisak da bi globalni rast kamatnih stopa $\mathrm{u}$ svetu mogao ograničiti finansiranje investicija, jer kamate smanjuju profit. Kod zemalja čije valute depresiraju, uvećava se teret servisiranja spoljnog duga denominovanog u dolarima, što obeshrabruje korporativni sektor za dalje investiranje (UNCTAD, 2017, str. 5). 
the outbreak of the financial crisis in 2008, which required the significant state financial assistance. These expenditures significantly increased the public debt that was already high due to a fiscal imbalance (Laeven and Valencia, 2013). The high private sector's indebtedness in the Southeastern European countries can also be a factor responsible for the destabilization of the public sector in those countries. This is especially noticeable in the countries with high and rising levels of non-performing loans (NPLs).

On the other hand, the revival of exports in recent years has contributed to the increase in export revenues, which has affected the reduction of the above-defined external debt coefficient. Nevertheless, in several SEE countries the value of this coefficient exceeds $200 \%$. This actually indicates that the level of external indebtedness of the countries in this region is high, and that in the coming years, the support must be sought in the increased inflow of FDI. In this way, the external debt service may relax, thereby creating the possibility of maintaining a small CA deficit without additional external borrowing. However, one must not forget the fact that a large FDI inflow means that the repatriation of the realized profit can be expected in the future, rather than its infinite reinvestment. This will imply an increased outflow of capital, while reducing the net inflow of FDI as an important source of financing the CA deficit. At that moment, the country must reduce their CA deficit toward the sustainable levels compliant with the available resources for its financing.
A significant source for financing the CA deficit of Southeastern Europe is the FDI inflows. The inflows of these funds are given in Chart 6.

Savings in the Western Balkan countries are still lower than the investment requirements, so the disparity is filled with foreign funds. The expansion of the CA deficit, stimulated by the acceleration of economic activity in the period before the outbreak of the global economic crisis in 2008, was largely financed by FDI inflows as well as foreign loans. However, a significant portion of this inflow was directed to the sectors that produce for the domestic market. As a result, these funds did not significantly affect the productivity growth or the expansion of production for export purposes. Along with the CA deficit increase, the surplus of the financial account in the Western Balkan countries has grown. This generated the tendency for growth of foreign exchange reserves, which doubled in comparison to the usual amounts. For most Western Balkan countries, FDI is the main source of external financing (The World Bank, 2016 p. 9).

Based on the current trends in the international capital market, the impression is that the global growth of interest rates could limit investment, as the interest rates reduce profits. In the countries whose currency depreciates, the burden of servicing the external debt denominated in dollars increases, which discourages the corporate sector from further investment (UNCTAD, 2017, p. 5).

Chart 5: External debt of SEE countries (\% of exports of goods, services and primary income)

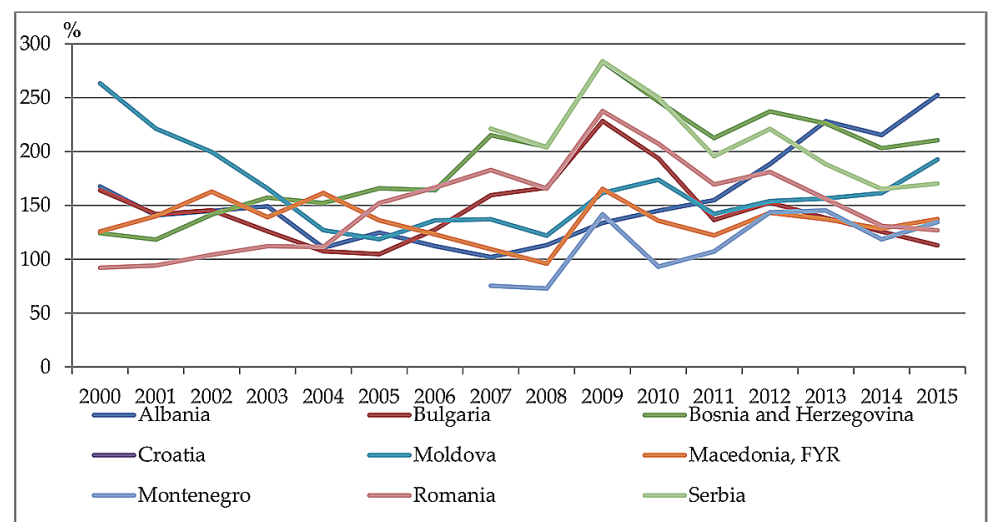

Source: The World Bank, http://data.worldbank.org/indicator/NE.EXP.GNFS.

ZS? view=chart Accessed 20.08.2017 
Grafikon 6. Neto priliv SDI kao procenat BDP-a

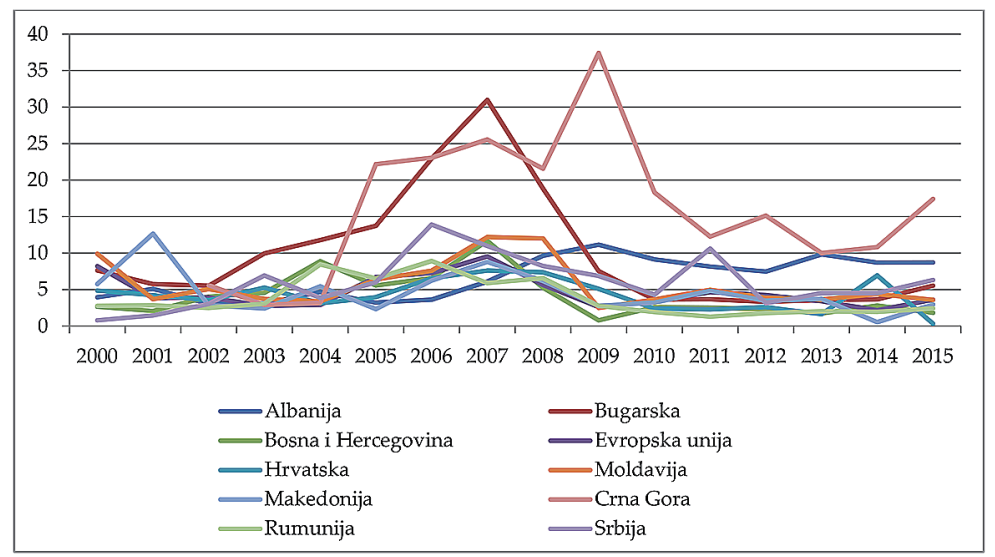

Izvor: The World Bank, http://data.worldbank.org/indicator/NE.EXP.GNFS. ZS?view=chart Pristup 20.08.2017.

spoljnog duga, koji je služio za finansiranje rastućeg deficita tekućeg računa. Sa porastom strane zaduženosti rastao je i iznos servisiranja tog duga, tako što je sve veći deo izvoznih prihoda usmeravan za te namene. Problem svih zemalja JIE leži u tome što su inostrana sredstva uglavnom korišćena za finansiranje tekuće potrošnje i proizvodnje nerazmenljivih proizvoda. Jednim delom ova sredstva su utrošena za finansiranje infrastrukture, što

Kod većine zemalja ovog regiona registrovan je porast priliva doznaka iz inostranstva (grafikon 7). Ovaj vid deviznog priliva predstavlja važan izvor za finansiranje jednog dela deficita trgovinskog bilansa. Lider među zemljama jugoistočne evrope po prilivu doznaka je Moldavija, a slede je Bosna i Hercegovina, Crna Gora i Srbija. I kod ostalih zemalja ovaj priliv igra značajnu ulogu. To je razlog da se kreiraju podsticajne mere koje bi doprinele da se poveća priliv ovih sredstava i kroz investicionu motivaciju.

Grafikon 7. Priliv privatnih doznaka u zemlje jugoistočne Evrope (u \% od BDP-a)

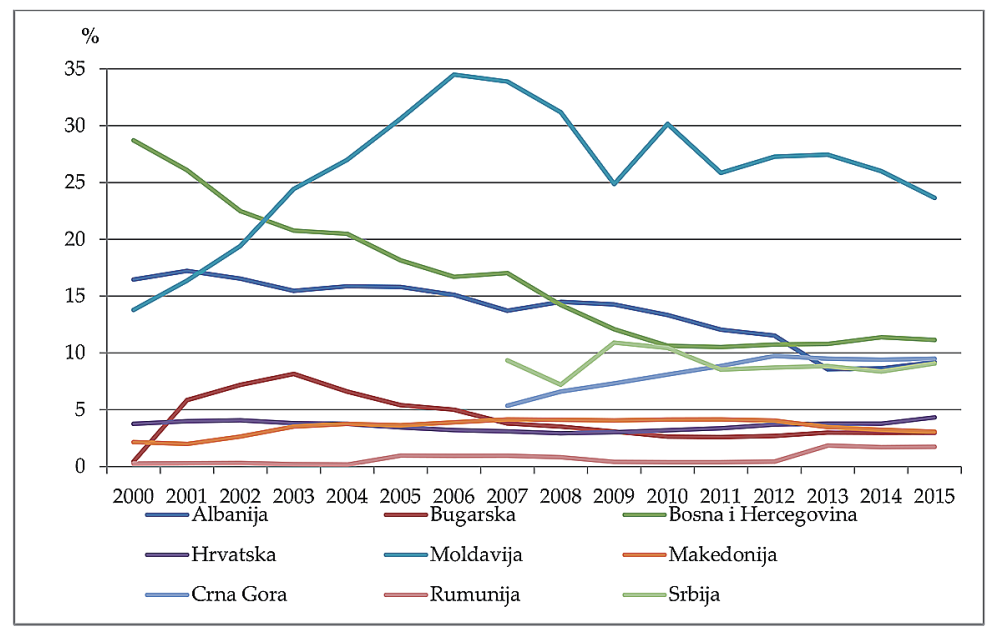

Izvor: The World Bank, http://data.worldbank.org/indicator/NE.EXP.GNFS. ZS?view=chart Pristup 20.08.2017.

\section{Zaključak}

Zemlje JIE su u periodu pre izbijanja globalne ekonomske i finansijske krize $\mathrm{u}$ svetu 2008. godine akumulirale visok iznos je podstaklo priliv SDI. Ipak, glavna poluga za stimulisanje priliva SDI su poreske olakšice i stimulacije za novo zapošljavanje. Spoljni dug zemalja ovog regiona je dostigao visok iznos kad preti opasnost prelaska u zonu prezaduženosti. Tendencija širenja deficita tekućeg računa je prekinuta posle izbijanja globalne finansijske krize, a usledilo je prilagođavanje u vidu znatnog smanjivanja ovog deficita $\mathrm{u}$ odnosu na BDP. Kod većine zemalja JIE ovaj deficit se krajem 2015. godine kretao u rasponu od 0 do 10\% BDP-a. Uz kontinuiran neto priliv SDI, ovaj iznos deficita tekućeg računa mogao bi se smatrati održivim na srednji rok. Naravno, važno je da SDI $\mathrm{u}$ velikoj meri budu plasirane $\mathrm{u}$ izvozni sektor. Uostalom, strategija privrednog rasta trebalo bi da bude zasnovana na izvozu. Međutim, rast kamatnih stopa na međunarodnom tržištu kapitala nagoveštava porast tereta servisiranja spoljnog duga i manje profite $\mathrm{u}$ korporativnom sektoru, što može usporiti rast neto priliva SDI. U tom slučaju, alternativa za finansiranje deficita tekućeg računa $u$ dostignutim razmerama je dodatno zaduživanje u inostranstvu. Međutim, ta opcija je za neke zemlje već iscrpljena jer je njihov spoljni dug blizu 80\% njihovog BDP-a, granica preko koje se prelazi u stanje prezaduženosti. Zemlje ne mogu sebi dopustiti taj luksuz jer se sa 
Chart 6. Foreign direct investment, net inflows (\% of GDP)

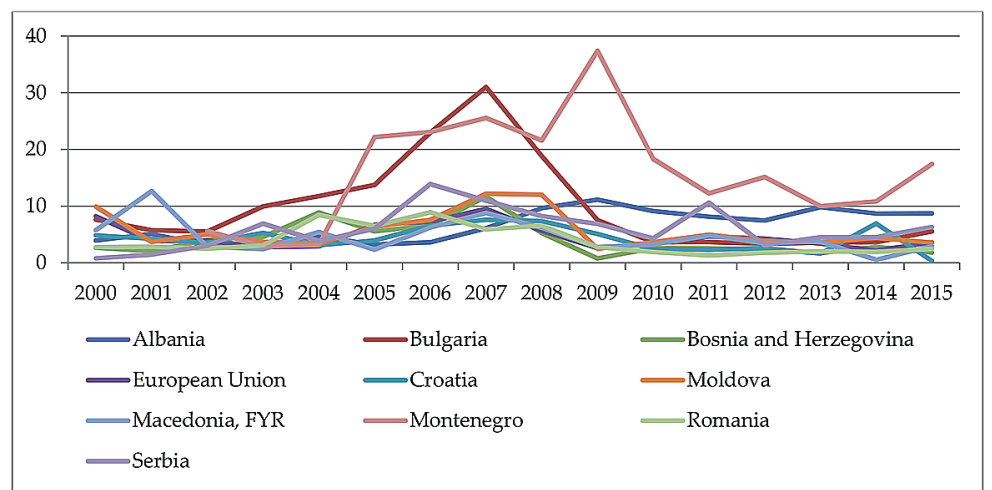

Source: The World Bank, http://data.worldbank.org/indicator/NY.GDP.MKTP. CD?view=chart Accessed 20.08.2017

In most countries in the region, there has been an increase in remittances inflows from abroad (Chart 7). This type of foreign exchange inflow is an important source for financing a part of the trade deficit. Moldova is the leader among the Southeastern European countries according to remittances inflows, followed by Bosnia and Herzegovina, Montenegro and Serbia. In other countries, this inflow plays a significant role. This is the reason to create incentive measures that would contribute to increasing the inflow of these funds through investment motivation.

indebtedness, the level of debt servicing has also grown, with an increasing proportion of export revenues being channeled for these purposes. The problem of all SEE countries lies in the fact that foreign funds are mainly used to finance the current consumption and production of non-tradable goods. In part, these funds were spent to finance the infrastructure, which prompted the FDI inflows. However, the main factors for stimulating FDI inflows are tax incentives and incentives for new jobs. The external debt of SEE countries has reached a high level with the danger of crossing this limit. The rising CA deficit was interrupted after the outbreak of the global financial crisis, followed by an adjustment in the form of a significant reduction of this deficit relative to GDP. In most SEE countries, this deficit ranged from 0 to $10 \%$ of GDP at the end of 2015. With a continuous net inflow of FDI, this amount of CA deficit could be considered sustainable in the medium term. Of course, it is important to get FDIs largely directed into the export sector. After all, the strategy of economic growth should be based on exports. However, the increase in interest rates on the international capital market implies an increase in the burden of debt servicing and less profits in the corporate sector, which can slow down the growth of net FDI inflows. In that case, the alternative way for financing the CA deficit is the additional external debt. However, this option has already been exhausted for some countries because their

\section{Conclusion}

In the period before the outbreak of the global economic and financial crisis in 2008, the SEE countries have accumulated a high level of external debt, which used to finance the growing CA deficit. With the rise of external external debt is close to $80 \%$ of their GDP, the boundary when over-indebtedness becomes unavoidable. These countries cannot afford this luxury, because the transition to a state over-indebtedness exacerbates the conditions of external borrowing, and an increasing part of the foreign exchange inflows is separated 
prelaskom u stanje prezaduženosti pogoršavaju uslovi spoljnog zaduživanja, a sve veći deo deviznog priliva odvaja se za servisiranje spoljnog duga. U toj situaciji zemlje bi morale da pristupe strukturnom prilagođavanju koje bi podrazumevalo dalju redukciju deficita tekućeg računa i njegovo svođenje u okvire koji su održivi sa stanovišta raspoloživih izvora za njegovo finansiranje.

\section{Literatura / References}

1. Alfaro et al., 2017. Lessons Unlearned? Corporate Debt in Emerging Markets, NBER Working Paper 23407. Cambridge: National Bureau of Economic Research.

2. Cesaroni, T., and De Sant, R. 2015. Current account "Core-periphery dualism" in the EMU, LEQS Paper No. 90/2015. London: LSE.

3. Constantinescu, C. et al. 2015. The Global Trade Slowdown: Cyclical or Structural?, Policy Research Working Paper 7158, Washington, D.C.: The World Bank.
4. Gabrisch, H. 2015. Net Capital Flows to and Real Exchange Rate of Western Balkan Countries. Economic Annals, Vol. LX, No. 205 / April-June, DOI:10.2298/EKA1505031G

5. Kinoshita, Y. 2011. Sectoral Composition of FDI and External Vulnerabilty in Eastern Europe, IMF Working Paper, 123, Washington, D.C.: International Monetary Fund.

6. OECD 2013. Trade in Intermediate Goods and International Supply Chains in CEFTA, CEFTA Issues Paper 6, Paris: OECD. 
for the purpose of external debt servicing. In this situation, the countries should undertake a structural adjustment that would imply a further reduction of the CA deficit and bring it back within the borders that are sustainable from the point of view of available resources for its financing.
7. Sanfey et al. 2016. How the Western Balkans can catch up, EBRD Working paper No. 186. London: EBRD.

8. UNCTAD 2017. World Investment Report 2017: Investment and Digital Economy. Geneva: UN.

9. World Bank Group 2016. South East Europe Regular Economic Report No.10: Resilient Growth Amid Rising Risks, Washington, DC: The World Bank.
10. World Bank Group 2017. Global Economic Prospects: A Fragile Recovery. Washington, DC: The World Bank.

11. Wyplosz, C. 2013. Europe's Quest for Fiscal Discipline, European Economy Economic Papers 498. Brussels: European Commission. 